\title{
パワーエレクトロニクス製品を支える実装技術
}

\section{Mounting Technologies for Power Electronics Products}

電子部品・実装技術委員会

\section{1.はじめに}

近年, 省エネや地球環境保護の観点から, パワーエレク トロニクスへの注目が高まっている。エアコンや冷蔵庫な どの家電製品のインバー夕制御や, 昇降速度と快適性を両 立している高層ビルのエレベータ, 高効率な高速走行を実 現している新幹線などの電鉄車両, 低燃費で $\mathrm{CO}_{2}$ 排出量の 少ないハイブリッド電気自動車などが代表例に挙げられる。

本稿では, IGBT (Insulated Gate Bipolar Transistor) 素子や FWD (Free Wheeling Diode) 素子を搭載したパワーモジュー ル（IGBT モジュール）を中心に, 大容量・小型・高信頼 性の実現に必要な低熱抵抗・高耐圧・高耐熱パッケージ技 術の動向 ${ }^{1)}$ やそのパワーエレクトロニクスを支え, 発展さ せるべく実用化が検討されている材料技術について述べる。

1.1 パワーエレクトロニクスに注目される半導体デバイス パワーエレクトロニクスの電力の変換・制御の中心的な 役割を IGBT などのパワー半導体デバイスが担っている。

現在, IGBT は高耐圧 - 大電力容量 (数十 $\mathrm{V} \sim$ 数 $\mathrm{kV}$, 数 $\mathrm{A}$ 〜数千 A）で, さらに高速スイッチング動作（～10 kHz） が可能なため, 幅広い範囲に適用されている。第 1 世代が 上市されてからすでに 20 年が経過し, この間 $\mathrm{Si}$ デバイス である IGBT はデバイス構造の技術革新により大幅に損失 特性の改善が行われてきている。しかし, 近年パワーデバ イスの適用範囲の拡大や細分化が急速に進展しており, 用 途に応じた最適なデバイスの開発が必要となっている。

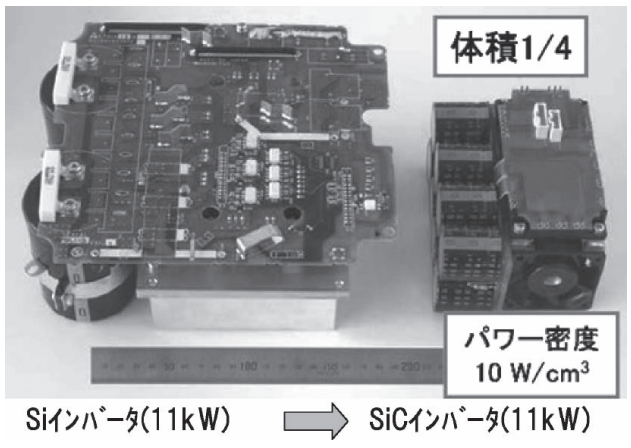

図 1.SICパワーデバイスを用いたインバータの小型化
また，最近では次世代のパワーデバイスとして， $\mathrm{SiC}$ (Silicon Carbide) などのワイドバンドギャップデバイスが注 目と期待を集めている。 $\mathrm{SiC}$ デバイスは，バンドギャップ が $\mathrm{Si}$ の約 3 倍, 破壊電界強度が 10 倍以上, また高温動作 ができることなど優れた特性を有しており，特に電力変換 装置への適用時に電力損失を大幅に低減することが可能に なると見込まれている ${ }^{2)}$ 。図 1 には $\mathrm{SiC}$ パワーモジュール を用いたインバータの事例を示すが， $\mathrm{SiC}$ デバイスを用い ることで，製品の小型化できるなど期待されている ${ }^{3)}$ 。

他方, 半導体デバイスは, チップ形態のままでは装置に 組込んで使用することができないため，パッケージにする 必要がある。この際, 複数のチップを用いて回路を構成し たものがパワーモジュールである。パワーエレクトロニク スに用いられるパワーモジュールは電流密度や破壊耐量が 高く，かつコンパクトで使いやすいことが望まれており， これら要求を達成するためのパッケージ技術が急速に進展 している ${ }^{4)}$

\section{IGBT モジュールの構造と構成材料}

図 2 に代表的な IGBT モジュールの外観とハーフブリッ ジ $(2 \mathrm{in} 1)^{\dagger}$ 回路構成を示す。IGBT モジュールは, 主にモー 夕制御などの電力変換に用いるため, ハーフブリッジある いは 3 相ブリッジ (6in 1$)^{\dagger}$ の回路構成が主に採用されてい る。図 3 にモジュール断面構造を示す。チップ上で発生し た熱を効率的に逃がすために，放熱板上にチップと絶縁基 板をはんだ接合された積層構造となっている。さらに，放
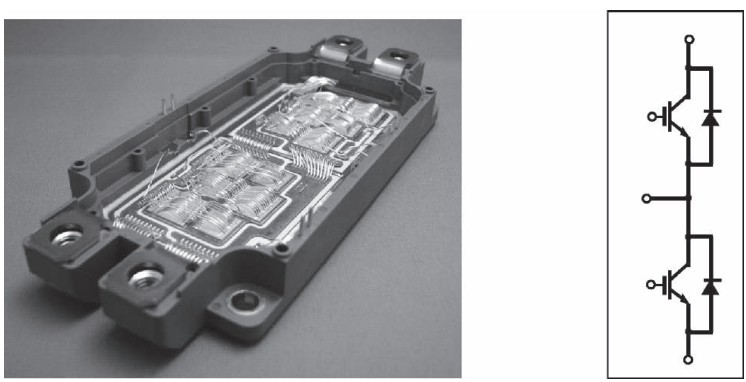

図 2. IGBT モジュールの外観と回路構成 


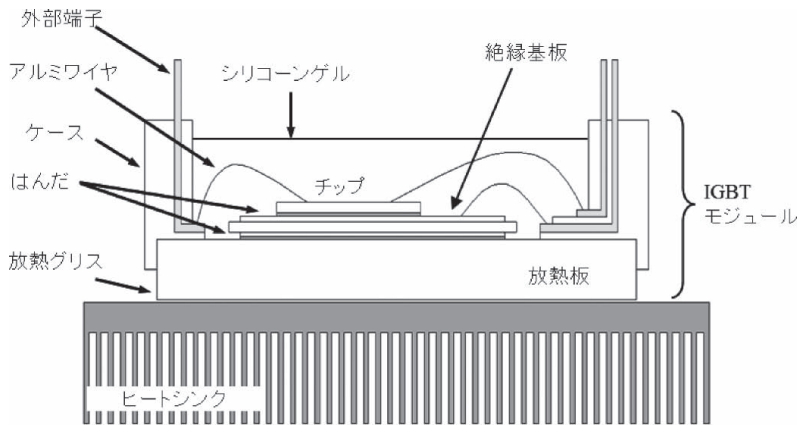

図 3. IGBT モジュールの断面構造

熱板には外部端子を内蔵したケースが接着され，チップお よび絶縁基板の電極と外部端子はアルミワイヤにて接続さ れている。モジュール内部はシリコーンゲルが充填され外 部環境から保護されている。

これら IGBT モジュールを構成する材料および部品につ いて機能面から 1) 絶縁・放熱，2) 接合・接続，3) 保護・封 止に分け，各々の役割について述べる。

\section{1 絶緑・放熱部品材料}

\subsection{1 絶縁基板}

主な機能は，i） IGBT のエミッタおよびコレクタ電極 と GND（対地）との絶縁の確保, ii ）回路形成, iii）チッ プで発生した熱を放熱板に伝えることである。したがっ て, 絶縁基板は絶縁破壊特性, 熱伝導率および機械的特性 （強度・破壊靱性）が重要となる。基板材料として, 主にセ ラミックス（アルミナ, 窒化アルミニウム, 窒化珪素など) が用いられ，セラミックスの表亭に銅やアルミニウムの金 属回路が形成されている。

\subsection{2 放熱板}

主な機能は，チップで発生した熱をヒートシンクに伝え ることである。そのため, 適用される材料としては, 熱伝 導に優れた銅やアルミニウムなどの金属が用いられる。た だし，放熱板には絶縁基板が接合されるため, 絶縁基板と の熱膨張率差が接合部の信頼性寿命に影響する。

電鉄や自動車などの高い信頼性が必要な用途に用いられ る放熱板材料には，絶縁基板に熱膨張率をあわせた低熱膨 張率の $\mathrm{AlSiC}$ や $\mathrm{CuMo}$ などの複合材料も用いられている ${ }^{5)}$ 。

\section{2 接合・接続部品材料}

\subsection{1 はんた}

主にチップ，絶縁基板および放熱板の接合に用いられ る。特にチップと絶縁基板の接合に用いられるはんだは, 高い熱伝導特性と耐熱特性が要求される。はんだ組成とし ては，以前は Sn-Pb 系はんだが適用されていたが，環境規 制の高まりにより近年は RoHs 指令などに対応した Sn-Ag 系， $\mathrm{Sn}-\mathrm{Cu}$ 系拉よび $\mathrm{Sn}-\mathrm{Sb}$ 系などの鉛フリーはんだが多く 用いられている。

\subsection{2 ワイヤ}

チップ表面電極と絶縁基板および外部端子などとの接続

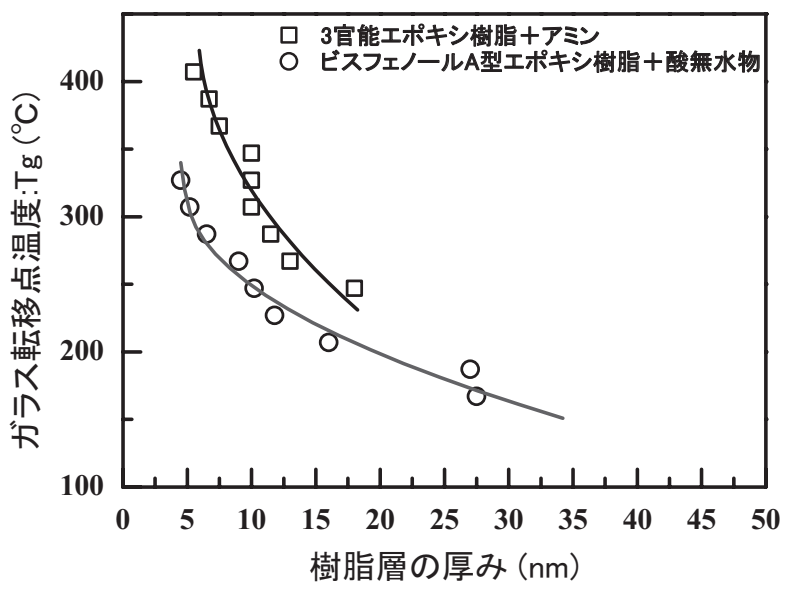

図 4. エポキシ樹脂層厚さと $\mathrm{Tg}$ の関係 ${ }^{8)}$

に用いられる。接続方法は，超音波による固相拡散接合法 が用いられる。ワイヤ材料は高純度アルミニウムが一般的 に用いられており，接合条件に即した機械的特性（強度・ 伸び）が必要とされ，調質（焼入れ，焼き戻し）が重要と なる。

近年，電気抵抗の低い銅ワイヤも採用され始めている が，銅はアルミニウムに比べて硬いため，チップ表面電極 への接続に際してはチップ破壊の防止が課題となっている。

\section{3 保護・封止材料}

\subsection{1 ケース}

主な機能は，筐体の役割と外部電極端子の支持である。 ケース用材料は，機械的特性（強度・勒性・耐衝撃）が重 要である。ケース材料の種類は主に, PPS（ポリフェニレ ンサルファイド）や PBT（ポリブチレンテレフタレート） などのエンジニアリングプラスチックスが用いられてい る。射出成形により金属製端子を包埋した複雑形状に成形 される場合もあるため成形性も重要な材料特性である。

\subsection{2 封止樹脂}

主な機能は, チップをはじめとする内部構造の外部環境 からの保護㧍よび回路間の絶縁である。封止材料の種類 は，シリコーン系樹脂（シリコーンゲル）が主に用いられ ている。封止樹脂は，発熱源であるチップと直接接するこ とから耐熱性, さらに, 回路間と接し界面を形成しつつ絶 縁を確保するため密着性が重要となる。使用環境によって は耐水性や耐腐食ガス性を考慮することも必要である。近 年では，高耐熱化の取組みとしてエポキシ樹脂による封止 が行われており，エポキシ樹脂の更なる高耐熱化の検討も なされているの。これまで熱可塑樹脂をべース材としてナ ノフィラーを添加した高耐熱化の検討は多くなされている が7)，ナノシリカを添加したエポキシ樹脂の高ガラス転位 点温度 $(\mathrm{Tg})$ 化など, 高絶縁機能を持つ熱硬化樹脂へのナ, フィラー添加による高耐熱化の開発はあまりなく，現在盛 んに検討がされている。例えば，図 4 に示すようにナノ フィラーの添加により，粒子間に存在するエポキシ樹脂の 
厚さが, 見かけ上薄くなることで, 高 $\mathrm{Tg}$ 化が可能なこと が報告されている ${ }^{6), 8)}$ 。これはナノフィラーの添加により， 樹脂の分子鎖の緩和運動が $\mathrm{Tg}$ 温度近傍で抑制されると考 えられており, フィラーを分散させ, 約 $100 \mathrm{~nm}$ 程度以下 の樹脂層の厚さを実現することで, $\mathrm{Tg}$ が約 $30^{\circ} \mathrm{C}$ 程度向上 することが報告されている。

\section{3 高温動作を実現する高耐熱技術と材料技術}

高温動作化が進むパワーモジュールにおいて特に高耐熱 化が必要となるのは，接合・接続部である。図 5 にパワー モジュールの接合・接続部における熱破壊モードを示す。

チップのスイッチング（オン・オフ）動作のモード（短 時間の温度サイクル）によってアルミワイヤ接合部および チップのはんだ接合部が熱疲労劣化により破壊する。アル ミワイヤ接合部の疲労破壊は, アルミワイヤの結晶粒の粗 大化とチップ電極の熱劣化も同時に進行する複合破壊を呈 する。

以下に，各接合部の高耐熱化について述べる。

\subsection{1 ワイヤ接合部}

ワイヤ自身の高耐熱化手法として，i）添加元素による アルミの耐熱性向上， ii） ワイヤ材質の変更（銅ワイヤの 適用）がある。

図 6 に添加元素によるアルミの高耐熱化の検討例を示す。 上段は, 添加元素無しの初期とパワーサイクルや後の結
晶粒子の形態であり，下段は添加元素有りの形態である。 添加元素無しのアルミの結晶粒子は初期に比べてパワーサ イクル後は粗大化している。添加元素有りでは初期とパ ワーサイクル後で結晶粒子径に変化はみられず，高温下に おいて組織が安定しており，アルミワイヤの高耐熱化が図 られている9)。

銅ワイヤはアルミよりも耐熱温度が高く, 電気抵抗もア ルミに比べて小さい特徴を活かしてワイヤ本数の低減など のメリットが期待できるが, 反面硬く塑性変形しにくいた め, ボンディング時のチップへのダメージが懸念され, チップの電極膜を従来のアルミ膜から，より硬い別材料へ の変更の検討が必要となってくる。

さらに特性改善によりチップが大幅に小型化されること に伴い, 従来のワイヤボンディングから，より大きな電流 を流せるリードフレーム接続という方式もある ${ }^{4), 10) 。 ~}$

\subsection{2 はんだ接合部}

はんだは，金属接合材料の中では $300^{\circ} \mathrm{C}$ 以下の比較的低 い温度で溶融し，凝固した後の接合信頼性も維持できるた め，長年使われ続けられている便利な材料である。

$\mathrm{Si}$ デバイスは, 動作温度の限界が $175^{\circ} \mathrm{C}$ 近辺と言われ, この動作温度領域では，はんだが使用できる。しかし， $\mathrm{SiC}$ デバイスは, 動作温度が $200^{\circ} \mathrm{C} \sim 300^{\circ} \mathrm{C}$ でも可能であり, はんだ材料の溶融温度以上になる場合がある。

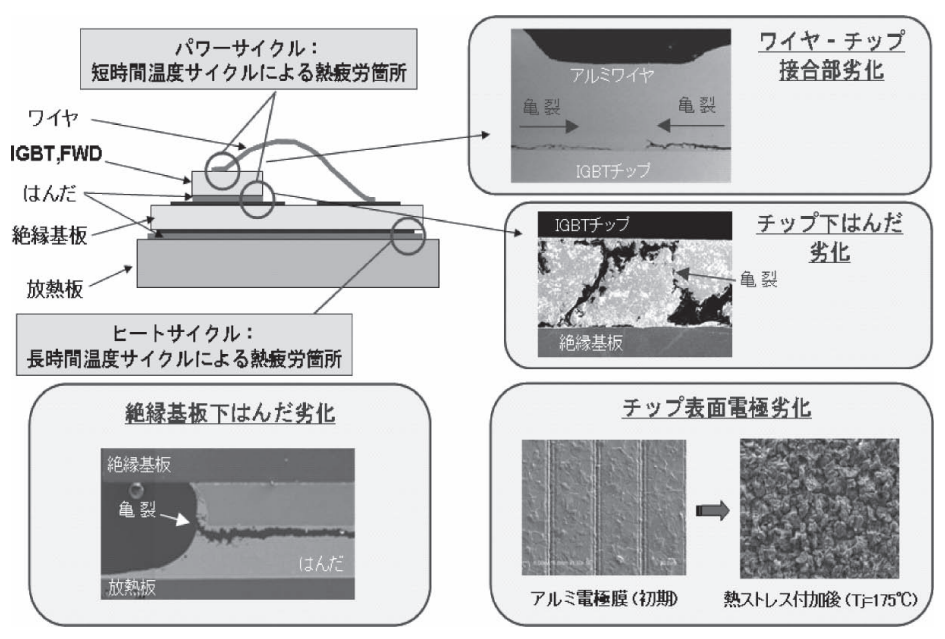

図 5.モジュールの熱破壞モード

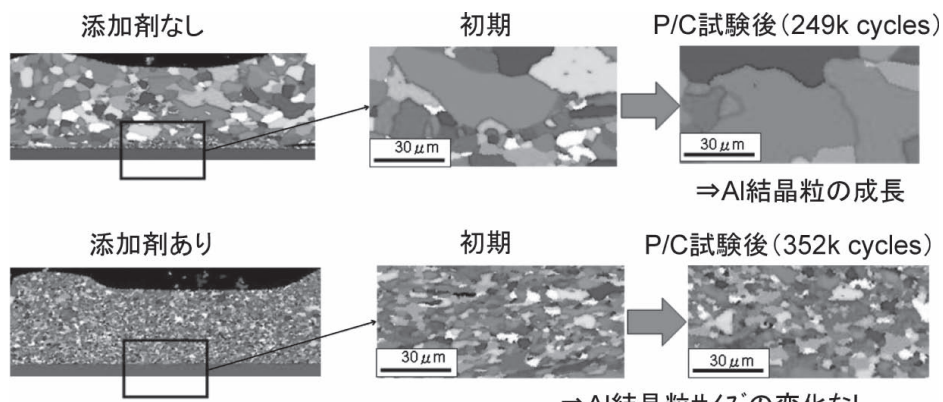

$\Rightarrow \mathrm{Al}$ 結晶粒サイズの変化なし

図 6. アルミ結晶粒子径粗大化比較 $\left(\mathrm{EBSD}^{\dagger}\right)$ 
はんだ材料に代わる代表的な高耐熱接合技術として金属 粒子焼結接合が挙げられる。特に, 実用化が進んでいるの が銀粒子を用いた焼結接合である ${ }^{11}$ 。金属粒子焼結は，互 いに接触する粉末粒子が表面の面積を減少する方向に物質 移動を起こすことにより, 粉末粒子間に結合（融着）が生 じて緻密化し塊状の多結晶体となる現象を利用しており, さらに粉末粒子径をミクロンオーダー以下にすることで粒 子同士が結合する温度をその粒子材の融点以下にし, 焼結 後は粒子材の融点まで溶融しないという特徵がある。

銀ナノ粒子の焼結接合温度は, $300^{\circ} \mathrm{C}$ 以下の加熱と 20 $\mathrm{MPa}$ 以下の加圧で金属接合が得られ, 高耐熱（溶融温度 : 約 $900^{\circ} \mathrm{C} ）$ の接合技術として害用化が検討されている。

焼結接合層は，はんだ接合層に比べて高強度，高耐熱か つ低熱抵抗であり，動作温度が高温化しても信頼性が高 く, 高い放熱性が確保できる。しかしながら, 大面積の接 合に用いる場合，はんだに比べて非常にコスト高となるた め, 貴金属粒子の焼結接合材料にかわる, 低コス卜な材料 の開発によって, 量産化の拡大に今後繋がるものと考える。

他方，プリント回路板に実装され，2段階リフロー工法 に用いられる, パワーデバイス内部のシリコンダイとのは んだダイボンディング部では, Bi 基合金など低コストで且 つ $260^{\circ} \mathrm{C}$ ピーク温度リフロー加熱に耐えうる溶解開始温度 （固相線温度）をもつはんだ材料の検討も盛んに行われてい る。候補材としては, $\mathrm{Bi}$ は融点が $271^{\circ} \mathrm{C}$ と $\mathrm{Pb}$ に近く, 弾 性率は $32 \mathrm{GPa}$ と $\mathrm{Sn}-\mathrm{Pb}$ 系はんだ合金に近い特性を持ってお り，Biが注目されている。しかし，Bi は三方晶であり， FCC や BCC 構造の金属材料と比較し，すべりによる塑性 変形がし難いことが知られ， $\mathrm{Bi}$ 基合金の力学特性の結晶方 位依存性や温度依存性は, 未だに多くが明らかにされてい ない。 $\mathrm{Bi}$ 基合金は接合性の課題も挙げられる。パワー系デ バイスを接合する部材には $\mathrm{Cu}, \mathrm{Ni}$ などが多く用いられて いるが, $\mathrm{Cu}$ と Bi は非常に接合性が悪い。Niでは，Bi 中へ $\mathrm{Ni}$ が非常に容易に溶解し, 約 10 数 $\mu \mathrm{m}$ の過剩な BiNi 化合 物が形成され, Ni との接合界面の力学特性を低下させる㲘 念が生じる。

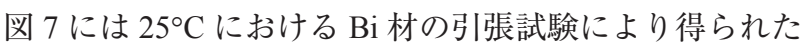
真応力ー真ひずみ曲線を示す。一般的には Bi は脆性材料と して知られているが, 図 7 に示すようにBi は双晶変形によ りすべり系を増加させながら延性挙動を示すことが報告さ れている ${ }^{12)}$

また高温にすることにより，降伏応力は低下し，破断延 性が 2〜3 倍増加する。低延性である $\mathrm{Bi}$ が，75〜 $125^{\circ} \mathrm{C}$ の 領域では $40 \sim 60 \%$ の伸びを示し, このことは, 現在主流で ある $\mathrm{Sn}-\mathrm{Ag}-\mathrm{Cu}$ 系はんだと, さほど変わらない延性を示す 可能性が示唆される。

今後, Bi の温度依存性や延性に影響する活動すべり系の 研究が進み, 力学特性や濡れ性を向上させうる添加材な ど, $\mathrm{Bi}$ 基合金系の検討が活発化し，低コストな接合材料の

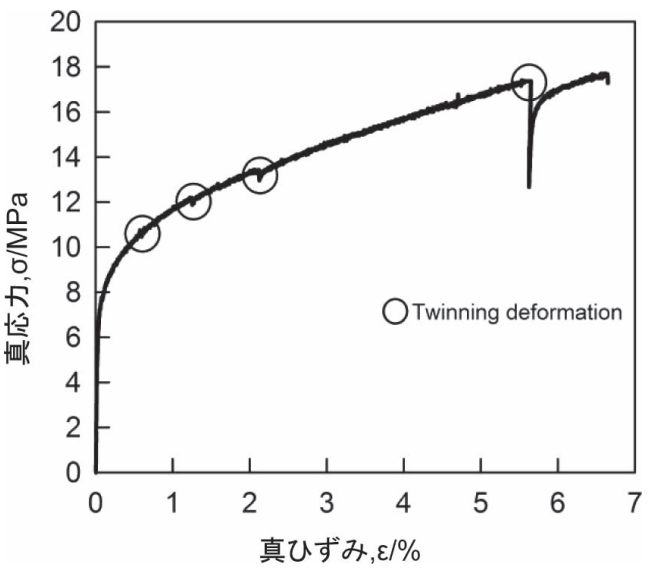

図 7. Bi 材料の真応力ー真ひずみ曲線 ${ }^{12)}$

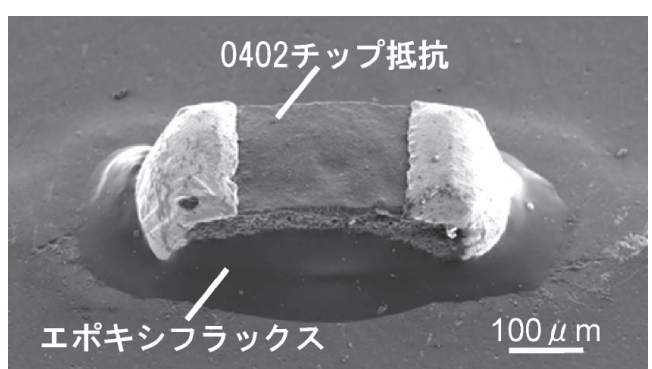

図 8. エポキシフラックスペーストによるはんだ接合外観

開発と高耐熱製品への活用が望まれる。

\subsection{3 エポキシフラックス}

古くから，部品実装では，ロジン系フラックスを用い て，はんだおよび接合部材の酸化物を除去し接合する方法 がとられている。パワーエレクトロニクス製品の高耐熱化 に対して, 軟化温度の低いロジン系フラックスからエポキ シを主剤としたエポキシ系フラックスの検討がなされてい る ${ }^{13)}$ 。重厚長大なパワーエレクトロニクス製品において も, 微細部品の採用が推進されており, 0402 チップ部品や バンプ接合などの，接合面積低下に伴う強度補強などが重 要な課題となる。

また高耐熱，高信頼性製品などでは，封止樹脂との相溶 性向上に効果的であると着目されている。図 8 には，一般 的なビスフェノール A P F 剂を主剤とし, 硬化剂に含まれ ているカルボン酸を酸化物除去に用いて接合した 0402 チッ プ抵抗部品の電子顕微鏡写真を示した。

0402 接合品をみてみると, 部品およびはんだ接合部周辺 に，エポキシ硬化物が包みこむように硬化していることが 確認できる。古くから使用されている低融点ロジン系フ ラックスに対し, 耐熱性向上や強度補強効果など, さまざ まな分野への応用も期待でき，このような製品アセンブリ 技術に必要な材料開発も，今後高耐熱製品の創出には重要 になると考えられる。 


\section{4. むすび}

冒頭でも述べたが, 省エネ, 電力供給不足などによる電 力価格はこれからも上昇すると考えられ，パワーエレクト ロニクス製品などを用いた, 省エネ化の推進は益々高まっ ていくと考えられる。今回それを実現するためのパッケー ジ技術の要求や動向, 高耐熱化に着目した材料技術につい て紹介した。パワーエレクトロニクス製品では, 耐熱, 高 温をキーワードに今後さまざまな開発が活発になされるこ とと考えられる。実装というと, パッケージや部品の技術 開発に着目されることが多いが, それを用いた製品として のアセンブリ技術などにも注視され，技術開発が進んでい くことが望まれる。

文責・渡邊裕彦・両角 朗 /富士電機

(2013.10.25- 受理)

\section{文献}

1) 高橋良和, 他 : “パワーモジュールのパッケージ技術動向, ” エレクトロニクス実装学会誌, Vol. 16, No. 5, pp. 341-346, 2013

2) 南川 明：“第 3 編, 第 1 章,”次世代パワー半導体, (株) エヌ・ティー・エス, pp. 307-312, 2009

3) 第 1 回「パワーエレクトロニクスインバー夕基盤技術開発」 (事後評価) 分科会：“研究開発成果, 実用化の見通し, ”資 料 5-2 (2), 2008

4) 高橋良和, 他：“次世代パワー半導体パッケージ・実装技 術, "17th Symposium on Microjoining and Assembly Technology in Electronics, pp. 187-192, 2011

5) Y. Nishimura, et al.: "Design of IGBT module packaging for high reliability,” Proceedings PCIM Europe 2010, pp. 249-254, 2010

6) 人見美也子, 他: “粗視化分子動力学を用いたポリマー界面 におけるガラス転移温度の解析, ”第 20 回ポリマー材料 フォーラム講演予稿集, p. 207, 2011

7) 尾崎多分, 他：“ナノ分散による高機能絶縁材料,”東芝レ ビュー, Vol. 59, No. 7, pp. 48-51, 2004

8) 竹松裕司, 他：“ナノコンポジットによるエポキシ樹脂の高 耐熱化,”電子デバイス実装研究会資料 ED-015-2013, pp. $31-35,2013$
9) T. Saitou, et al.: "New assembly technologies for $\operatorname{Tjmax}=175^{\circ} \mathrm{C}$ continuous operation guaranty of IGBT module," ISBN 978-38007-3505-1, Proceedings PCIM Europe 2013 conference, pp. $455-461,2013$

10) 富士電機 : 特許 3627591,2004

11) D. Berry, et al.: "Fabrication of a Double-side Cooling, High Temperature Power Module with Sintered Nanosilver Interconnect for Automotive Applications," ISBN 978-3-8007-3505-1, Proceedings PCIM Europe 2013 conference, pp. 1086-1093, 2013

12) 田嶋 翔, 他：“Bi の力学的特性とその変形挙動, ” 日本金 属学会秋季講演大会論文集, No. 550

13) 富士電機 : 特許 10159043,2010

\section{$\dagger$ 用語解説}

ハーフブリッジ (2in1)：4 個のスイッチング素子で構成 されたインバータ回路（フルブリッジ）に対して，2 個のスイッチング素子で 1 相を構成した回路。

3 相ブリッジ (6in1)：6 個のスイッチング素子で 3 相を構 成したインバータ回路。

パワーサイクル：素子に通電することによりスイッチン グを繰り返す動作。

EBSD : electron backscatter diffraction の略称。後方散乱電 子回折を利用して, 結晶性試料の方位解析をする方法。

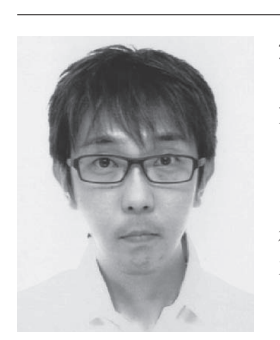

渡邊裕彦（わたなべ ひろひこ）

著者紹介

1991 年駿台電子情報専門学校卒業。2012 年群馬 大学大学院工学研究科博士課程修了。博士 (工学)。 現在, 富士電機株式会社生産技術センターに て，はんだ接合技術に従事。

エレクトロニクス実装学会 電子部品・実装技 術委員会 委員。スマートプロセス学会会員, 日 本金属学会会員, 溶接学会会員。

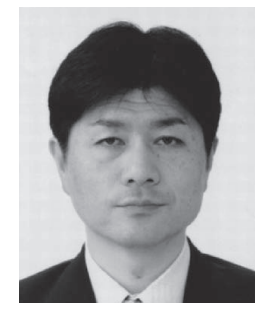

両角 朗（もろずみ あきら）

1988 年千葉工業大学工学部卒業。パワー半導体の 研究開発に従事。

現在，富士電機株式会社技術開発本部電子デバ イス研究所次世代モジュール開発センターパッ ケージ開発実装・設備技術グループ主査。 